\title{
Pastoralists' Perception of Resource-use Conflicts as a Challenge to Livestock Development and Animal Agriculture in Southeast, Nigeria
}

\author{
J. U. Chikaire, J. O. Ajaero, M. N. Ibe, E. F. Odoemenam \\ Department of Agricultural Extension, Federal University of Technology, Owerri, Imo, Nigeria, West Africa
}

Received: 01-11-2018; Revised: 12-12-2018; Accepted: 25-02-2019

\begin{abstract}
One of the major but hidden challenges to livestock development and animal agriculture in the world over is resource-use conflicts between crop farmers, pastoralists, and other land users. This is so because during conflict situation, almost all human livelihood activities come to a standstill including livestock farming. This study, therefore, sought to examine how conflicts involving different land users hinder livestock production. Questionnaire and oral interview were used to obtain information from a total of 120 pastoralists in three selected states of Southeast (Abia, Enugu, and Imo). Data were analyzed using percentages, mean, and standard deviation. The results showed that the mean age of pastoralists was 38, and the mean household size was 10, mean herding experience was 18 . The following were the causes of resource-use conflicts - blocking of water sources by crop farmers with a mean (M) response of 3.30, farming across cattle routes $(M=2.95)$, burning of fields $(M=3.30)$, and theft/stealing of cattle $(M=3.40)$, among others. The factors attracting the pastoralists to the study area were availability of special pasture $(\mathrm{M}=2.37)$, availability of land for lease $(\mathrm{M}=2.52)$, and water availability $(\mathrm{M}=2.60)$ among other reasons. Conflicts, therefore, affect livestock production in the following ways - unsafe field for grazing, poor animal health, loss of human and animal lives, abandonment of herds for dear life, and many others.
\end{abstract}

Key words: Agriculture, animal, conflict, livestock, pastoralists

\section{INTRODUCTION}

In Nigeria, grazing lands are rarely demarcated, and this large sector of agriculture always suffers compared to crop farming or fruit plantation. ${ }^{[1]}$ The latter two are mostly demarcated favorably for the fact that most people are sedentary and areas needed are small. The establishment of demarcated rangelands and passageways (cattle corridors) allows the livestock to access water points and pastures without causing damage to cropland (FAO, 2011). Pastoralists usually graze over areas outside farmlands, and these have been accepted to be the norm from time immemorial. Their movements are opportunistic and follow pasture and water resources in a pattern that varies seasonally or year to year according to availability of resources. ${ }^{[2]}$

\section{Address for correspondence:}

E. F. Odoemenam

E-mail: futoedu23@gmail.com
Livestock production in the form of pastoral livestock keeping is among the most suitable means of land use in arid areas of Africa due to its adaptability to highly variable environmental conditions. In Nigeria, most pastoralists do not own land but graze their livestock in host communities. ${ }^{[3]}$ While a few have adopted the more sedentary type of animal husbandry, the increasing crises between farmers and pastoralist presuppose that grazing is a major means of animal rearing in Nigeria.

The livestock sector in Nigeria is plagued by several challenges such as lack of adequate supplies of quality feed and pasture, diseases, weak market network, and unavailability of adequate water, and poor veterinary services ${ }^{[4-7]}$ reiterate that the sector is constrained by institutions, markets, and policy as well as technical issues. More recently concern on herdsmen-farmers' conflicts has appeared in literature and policy discourse as one of the formidable challenges facing livestock production (particularly ruminant) in many developing countries. 


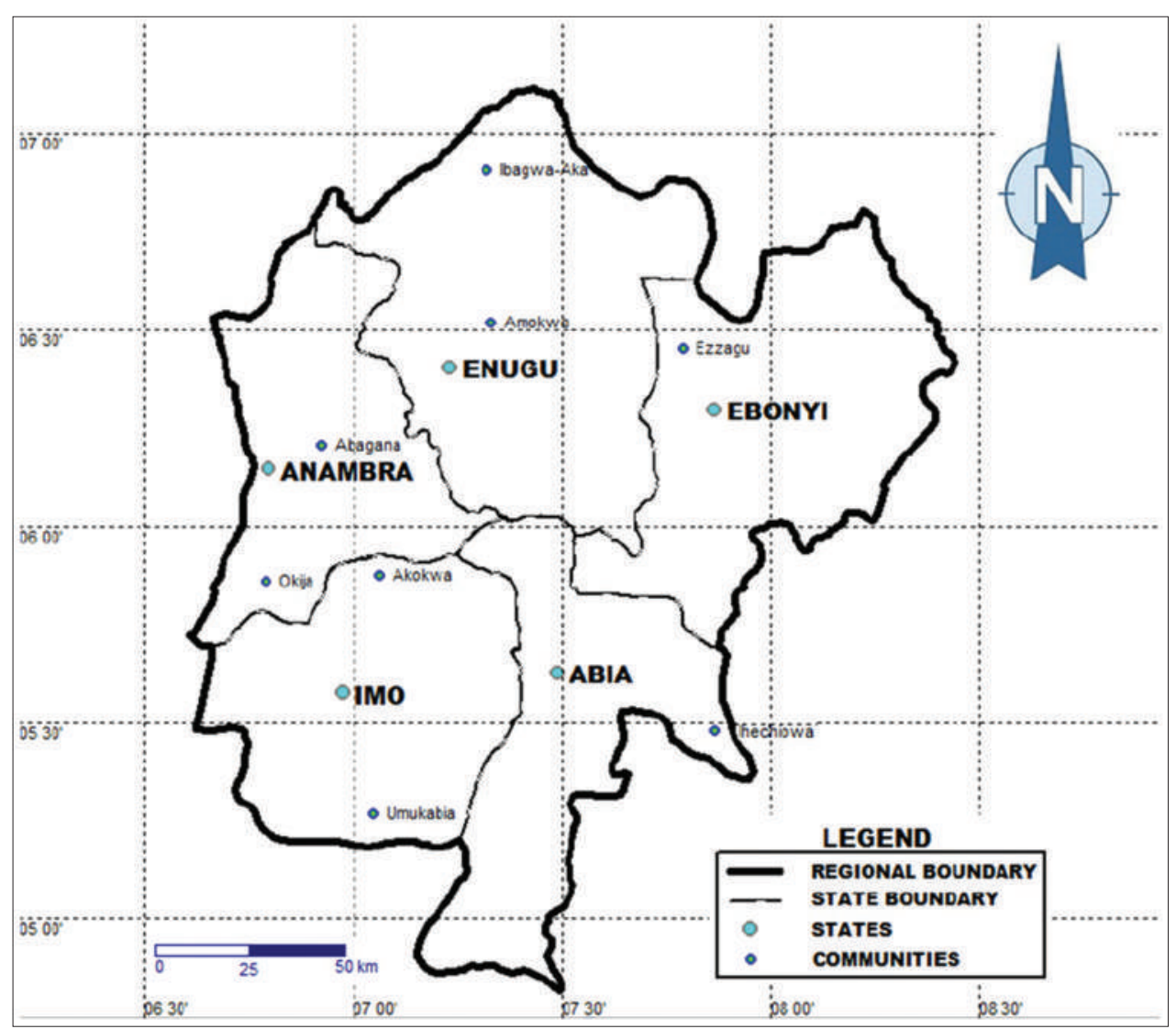

Figure 1: Map of Southeast Nigeria showing the three states under investigation (Abia, Enugu, and Imo)

Resource-use conflicts in Nigeria have persisted and stand out as a threat to national food security, livestock production, and eradication of poverty with pastoralists often regarded as the most vulnerable. Resource-use conflicts not only have a direct impact on the lives and livelihoods of those involved but they also disrupt and threaten the sustainability of agriculture and pastoral production in West Africa (Moritz, 2010). Hence, many land users make their livelihood within the same geographical, political, and sociocultural conditions, which may be characterized by resource scarcity ${ }^{[8]}$ or political inequality and population pressure. Pastoralists are believed to be more vulnerable compared with farmers because their cattle can be confiscated and/ or seized and released only on payment of a fine. Besides, sometimes they are in the minority and could lack political power to their advantage..$^{[9,10]}$ Resource-use conflicts/clashes according to Adisa and Adekunle, ${ }^{[11]}$ are becoming fiercer and increasingly widespread in Nigeria. A study of 27 communities in central Nigeria by Nyong and Fiki $^{[12]}$ shows that over $40 \%$ of households surveyed had experienced agricultural land-related conflicts, with respondents recalling conflicts that were as far back as 1965 and 2005. ${ }^{[13]}$ Showed that about 13 cases of farmer-herdsmen conflicts across states of the federation which claimed 300 lives of the citizens. In Abia, Enugu, and Imo States, there have been cases of conflicts between pastoralists and crop farmers in Umunneochi, Ugwunagbo, Uzo-uwani, Nkanu-West, Udi, Ohaji/Egbema, Owerri West, and Okigwe areas of the states over crop destruction by cattle, killing of herders, and stabbing of farmers following reprisal attack on different occasions. $^{[14]}$ Therefore, the study examined challenges of resource-use conflicts to livestock production in the Southeast region of Nigeria. It specifically sought to: a. Describe the socioeconomic attributes of respondents, $b$. examine causes of conflicts as perceived by the pastoralists, c. identify factors that attract the pastoralists to the state, and $d$. ascertain challenges of resource-use conflicts to livestock agriculture.

\section{METHODOLOGY}

This study was conducted in Southeast agroecological zone of Nigeria, characterized by tropical rainforest [Figure 1]. The Southeast agroecological zone lies within latitudes $5^{\circ} \mathrm{N}$ and $6^{\circ} \mathrm{N}$ of the equator and longitudes $6^{\circ} \mathrm{E}$ and $8^{\circ} \mathrm{E}$ of the Greenwich Meridian. Southeast Nigeria is made up of five states - Abia, Anambra, Ebonyi, Enugu, and Imo. The zone occupies a total land mass of 
about $10,952,400$ hectares with a population figure of about 33,381,729 persons in 2018 projected from 2006 National Population Commission Census figure (National Population Commission, 2006). About $60-70 \%$ of the inhabitants of the zone are observed to engage in agriculture, mainly crop farming and animal rearing. ${ }^{[15]}$ The two-stage sampling technique was adopted in the process of sample selection. The first stage was the purposive selection of three states from the Southeast agroecological zone where cases of farmer-pastoralists conflicts have occurred and were reported (Abia, Enugu, and Imo). The second stage involved the random selection of 120 pastoralists from the list of 180 pastoralists from their various camps in the three states. Both primary and secondary data sources were used. Simple descriptive statistics such as mean, percentage, and frequency distribution were used to analyze the socioeconomic characteristic of the respondent. Objective 1 was analyzed using percentage presented in table. Mean was computed on a 4-point Likert type rating scale of strongly agree, agree, disagree, and strongly disagree assigned weight of $4,3,2$, and 1 to capture the perceived causes of the conflicts (objective 2) and challenges of conflicts to livestock development (objective 4). The values were added and divided by 4 to get the discriminating mean value of 2.5. Any mean value equal to or above 2.5 was regarded as a major factor causing conflict and challenge to livestock development, while values $<2.5$ were regarded none. Again, mean was also computed for objective 3 which looked at factors attracting pastoralists to the area on a 3-point Likert type rating scale of very serious, serious, and not serious assigned values of 3,2 , and 1 . The values were added and divided by 3 to obtain a discriminating mean value of 2.0. Any value with mean equal to or $>2.0$ was considered very serious and vice versa.

\section{RESULTS AND DISCUSSION}

\section{Socioeconomic characteristics of respondents}

Table 1 showed that $83.3 \%$ of the pastoralists were married, while $16.6 \%$ were single. The predominance of married people among the pastoralists could be attributed to the complementarity experienced in farm labor provision at the household level. The man, woman, and children pool their physical reserves to keep the arm on course. It is worthy to note that there are
Table 1: Socioeconomic characteristics of respondents $(n=120)$

\begin{tabular}{lc}
\hline Characteristics & Frequency (\%) \\
\hline Marital status & $20(16.6)$ \\
Single & $100(83.3)$ \\
Married & \\
Education level & $5(4.2)$ \\
No formal education & $103(85.8)$ \\
Quranic education & $12(10.0)$ \\
Primary school & \\
Organizational membership & $90(75.0)$ \\
MACBAN & $30(25.0)$ \\
FYAN & \\
Ownership of cattle & $3(2.5)$ \\
Self & $25(20.8)$ \\
Politician & $35(29.2)$ \\
Alhaji/traditional ruler & $57(47.5)$ \\
Military officer & Mean \\
Other characteristics & 38 \\
Age & 10 \\
Household size & 18 \\
Herding experience & 61 \\
Herd size & N53.500 monthly \\
Income &
\end{tabular}

potential soldiers at the event of land-use conflict. Whereas $85.8 \%$ of the pastoralists had Quranic education, $10 \%$ had primary education, then, only $4.2 \%$ had no formal education. The pastoralists, all $(100 \%)$ belonged to social organizations; Islamic unions and/or herder unions. These respondents who belonged to social organization will likely benefit and share knowledge and experiences through contacts and cross-fertilization of ideas. The organization could also provide forum to plot, plan, and execute attack.

The table reveals that $47.5 \%$ of the pastoralists indicated that the animals are not their own but that of military officers, retired and serving. Some of the animals are also owned by Alhaji and traditional rulers in the north $(29.2 \%)$ who have established contacts with their kith and kin to protect their interest wherever they may be. Furthermore, 20.8\% and $2.5 \%$, respectively, are owned by the pastoralists themselves and few politicians who also trade in animals. The result explains the effrontery of the pastoralists and their seeming more powerful than the natives who are always helpless at their audacity. The mean age range was 38 years. This implies that the pastoralists are also young and can endure the difficult nature of their practice of trekking very long distance day and night. The average herding experience was 18 years. Experience is a valuable 
asset. The years of experience of the pastoralists could enable them to relate encounters they had causes, effects, and resolution. The mean herd size was 61 . This is indeed large and it reveals the fears of the crop farmers should cattle numbering into 30-100 invade their farms. A great deal of damage would be done; livelihood activities may be lost, food insecurity enthroned in addition to accentuated poverty. The average monthly income was N53.500.00. The pastoralists in their course sell the cattle and they also reproduce under their care.

\section{Perceived causes of resource-use conflicts}

Table 2 shows the pastoralists perception of the causes of the conflicts involving them and the crop farmers. Although they may seem to blame crop farmers from reality of telling the truth. To them, the causes of the conflicts included blocking of water source by crop farmers $(\mathrm{M}=3.30)$, farming across cattle routes $(\mathrm{M}=2.95)$, limited grazing areas $(\mathrm{M}=2.70)$, and burning of rangeland/field by crop farmers $(\mathrm{M}=3.28)$. They claim that farmers block the wells, ponds, and river routes where their animals drink. They also assert that farmers set their grazing areas ablaze and farm across their animal routes, thereby hindering their movement. Other causes of conflict were claim of land ownership $(\mathrm{M}=2.64)$ by the farmers; farmers fight herdsmen $(\mathrm{M}=3.00)$, setting of traps along the cattle way $(\mathrm{M}=2.74)$, harassment of pastoralists $(\mathrm{M}=3.01)$ by the youths, stealing/theft of cattle $(M=3.40)$, and poisoning of water source $(\mathrm{M}=2.80)$. The pastoralists see land as a free gift of nature and as such nobody should prevent others from the use of it and make laws regarding it against others. To them, land is for all and should be used as desired.

\section{Factors attracting pastoralists to the study area}

Table 3 shows that several factors attracted the Fulani pastoralists to the state. Among the factors were water availability with a mean $(\mathrm{M})$ response of 2.60 and availability of land to lease with mean score of 2.52. Water is life of both man and animals and the availability of streams and rivers in the Southern part of Nigeria becomes a reason for the pastoralists' invasion of Imo state. Again, even during the dry season, water sources remain intact as families get water either from streams, rivers, and even ponds. Land for lease or rent $(\mathrm{M}=2.52)$ to the head of the pastoralists is also available. These lands are mostly abandoned land not good enough for immediate crop production. The pastoralists are given this type of land for a specified period of time. Availability of special pasture with mean score of 2.37, market opportunity $(M=2.04)$, absence of tsetse fly $(\mathrm{M}=2.41)$, and support/backing from influential people with mean $(\mathrm{M}=2.11)$ were other reasons attracting pastoralists to the study area. Special pasture here means grasses and legumes that are highly nutritious to the animals and that can grow faster after being eaten by the animals. It involves digestibility, palatability and fastens reproduction of animals. This type of pasture draws the animals to the area often. Influential people in community also work with the pastoralists. These include traditional rulers who come in contact with the pastoralists, politicians, retired/serving civil servants, and military men retired/serving who have established relationship with the pastoralists. Since they have the backing/ support of those individuals, the pastoralists flock to the study.

Table 2: Perceived causes of resource-use conflicts

\begin{tabular}{ll}
\hline Perceived causes & Mean \pm SD \\
\hline Sexual harassment of crop farmers & $2.05 \pm 0.932$ \\
Blocking of water source by crop farmers & $3.30 \pm 0.833$ \\
Farming across cattle routes & $2.95 \pm 0.638$ \\
Limited grazing areas & $2.70 \pm 0.984$ \\
Population growth & $1.80 \pm 0.750$ \\
Burning of rangeland/field & $3.28 \pm 0.784$ \\
Claim of land ownership & $2.64 \pm 0.841$ \\
Farmers fight with herdsmen & $3.00 \pm 0.571$ \\
Setting traps for herds by crop farmers & $2.74 \pm 0.741$ \\
Harassment of nomads by community youths & $3.01 \pm 0.875$ \\
Theft/stealing of cattle & $3.40 \pm 0.916$ \\
Stealing of farm produce by nomads & $1.50 \pm 0.547$ \\
Contamination of stream by cattle & $2.00 \pm 0.578$ \\
Farm fragmentation & $1.80 \pm 0.645$ \\
Cultural differences & $2.50 \pm 0.784$ \\
Lack of respect for authority & $2.15 \pm 0.656$ \\
Poisoning of water sources & $2.80 \pm 0.745$ \\
\hline
\end{tabular}

Table 3: Factors that attract the Fulani man to the area

\begin{tabular}{ll}
\hline Factors & Mean \pm SD \\
\hline Availability of special pasture & $2.37 \pm 0.667$ \\
Availability of land to lease & $2.52 \pm 0.508$ \\
Support/backing from influential people & $2.11 \pm 0.386$ \\
Water availability & $2.60 \pm 0.351$ \\
Absence of tsetse fly & $2.41 \pm 0.670$ \\
Market opportunity & $2.04 \pm 0.570$ \\
\hline
\end{tabular}




\section{Conflicts as a challenge to livestock development and animal agriculture}

Conflict is a major challenge to livestock development and animal agriculture not only in the study area but also the world over. Any situation that brings chaos is not healthy for humans and animals as all will be restless and disturbed. ${ }^{[16]}$ Table 4 revealed that during conflicts, the grazing field for animals becomes unsafe as shown by a mean response of 3.30, poor animal health $(\mathrm{M}=3.27)$, animal/herd abandonment $(\mathrm{M}=3.38)$, loss of human lives $(\mathrm{M}=3.33)$, loss of farm income $(\mathrm{M}=3.37)$, cattle rustling/raiding $(\mathrm{M}=3.32)$, and high cost of animal products $(\mathrm{M}=3.25)$. The above situation presents a big challenge to animal agriculture as rearers of animals will put a stop to business and run for their dear lives, thereby making the livestock suffer neglect and abandonment. Due to concern for human lives and property, the business of animal rearing will take second fiddle, after all, the living will do the things that are important because there is life. Again, during conflict, livestock markets are closed $(\mathrm{M}=3.20)$ as both buyers and sellers will be in fear of going to the market to risk being attack. Market is an area where buying and selling and other economic transactions take place for the survival of man. When market for livestock is ceased, the

Table 4: Challenges of conflicts to livestock/animal agriculture

\begin{tabular}{ll}
\hline Perceived challenges & Mean \pm SD \\
\hline Unsafe field for grazing & $3.30 \pm 0.853$ \\
Poor animal health & $2.27 \pm 0.816$ \\
Animal/herd abandonment & $3.38 \pm 0.640$ \\
Insufficient food for livestock & $2.68 \pm 0.858$ \\
Insufficient beef supply & $2.50 \pm 0.877$ \\
Outbreak of animal diseases & $2.65 \pm 0.662$ \\
Loss of human lives & $3.33 \pm 0.828$ \\
Loss of farm income & $3.37 \pm 0.622$ \\
Loss of animals & $2.90 \pm 0.981$ \\
Forced migration of herders & $2.75 \pm 0.757$ \\
Poisoning of animal water source & $2.95 \pm 1.011$ \\
Cattle rusting/raiding & $3.32 \pm 0.853$ \\
High concentration of animals & $3.00 \pm 0.678$ \\
High cost of animal products & $3.25 \pm 0.638$ \\
Insecurity of trade routes & $2.98 \pm 1.025$ \\
Livestock market closures & $3.20 \pm 0.966$ \\
Lack of demand/reduced demand & $3.27 \pm 0.750$ \\
Total loss of pasture & $3.40 \pm 0.735$ \\
Reduced facilitating functions of animals & $3.21 \pm 0.967$ \\
Disrupt salable services of animals & $3.41 \pm 0.841$ \\
Abandonment of herds & $2.86 \pm 0.987$ \\
\hline & \\
\hline
\end{tabular}

economic life of the people is touched. Demand for livestock is reduced $(\mathrm{M}=3.27)$, total loss of pasture $(\mathrm{M}=3.40)$ where animals feed is also a challenge to livestock development and animal agriculture. Conflicts reduce the facilitating functions of animals $(M=3.21)$. Rearers of animals sell them for meeting up with their financial obligation and family responsibilities. The money from cattle and other animals facilitates the performance of other necessary roles, function and obligation sponsoring social gathers, and other traditional events.

Conflict changes the structure of livestock market which disproportionately affects the livelihoods of livestock producers and livestock traders as well as consumers' access to livestock products. Other major factors are insecurity of trade routes, market closures or destruction, lack of demand, the departure of traders from some conflict-affected counties, and forced migration of millions of heads of livestock. In some cases, herder's choices of migration routes were influenced by the need to protecting their livestock rather than feed and water availability. ${ }^{[17]}$

\section{CONCLUSION}

Conflicts between pastoralists and crop farmers in agrarian communities present a formidable challenge to livestock production in Nigeria. This is due to the problems of incompatibility of livelihood strategies, competition for access, and use of natural resources such as land and water. Pastoralists-crop farmers' conflict has production and economic consequences for herding. Among the most direct effects are loss of human lives, reduced number of livestock as well as reduced access to water, pasture, and even loss of homes. In addition, the conflicts lead to distrust in other communities and a strong omnipresent perception of insecurity which entails several and partly interconnected subsequent effects. These effects include ineffective resource use, reduced mobility, closing of markets, and schools and obstacles for investments. There is a need for effective conflict mitigation that breaks the cycle of violence, retaliation, and impoverishment. There is need to move from the conflicting to a cooperative path, which could start by addressing the capability of the actors.

\section{REFERENCES}

1. FAO. Grazing Reserves and Development Blocks: A Case Study from Nigeria Development Requirements; 
1985. Available from: http://www.fao.org/wairdocs/ilri/ x5539e/x5539e09.htm. [Last accessed on 2015 Feb 25].

2. FAO. Pastoralism and Rangel and Management; 2011. Available from: http://www.fao.org/docrep/014/i1861e/ i1861e10.pdf. [Last accessed on 2015 Mar 12].

3. Awogbade MO. Grazing reserves in Nigeria. Nomad People 1987;23:18-30.

4. Kassam A, Kueneman E, Kebe B, Ouedraogo S, Youdeowei A. Enhancing Crop-Livestock Systems in Conservation Agriculture for Sustainable Production Intensification: A Farmer Discovery Process Going to Scale in Burkina Faso Integrated Crop Management. Rome, Italy: Food and Agriculture Organization of the United Nations; 2009.

5. Mutibvu T, Maburutse BE, Mbiriri DT, Kashangura MT. Constraints and opportunities for increased livestock production in communal areas: A case study of Simbe, Zimbabwe. Livest Res Rural Dev 2012;24:9.

6. Peeling D, Holden S. The effectiveness of communitybased animal health workers, for the poor, for communities and for public safety. Rev Sci Technol 2004;23:253-76

7. Pell AN, Stroebel A, Kristjanson P. Livestock development projects that make a difference: What works, what doesn't and why. In: Swanepoel FJ, Stroebel A, Moyo S, editors. The Role of Livestock in Developing Communities: Enhancing MultiFunctionality. The Netherlands: CTA, Wageningen; 2010. p. 12-29.

8. Braukämper U. Management of conflicts over pastures and fields among the baggara Arabs of the Sudan belt. Nomad People 2000;4:37-49.
9. Bassett TJ. The political ecology of peasant-herders conflicts in the Northern Ivory coast. Ann Assoc Am Geogr 1988;78:453-72.

10. Blench RM. Conflict Between Pastoralists and Cultivators in Nigeria. Review Paper Prepared for DFID, Nigeria; 2010. Available from: http:/www.rogerblench. info.RBOP.tmm. [Last retrieved on 2015 May 20].

11. Adisa RS, Adekunle AO. Farmer herdsmen conflicts: A factor analysis of socio-economic conflict variables among arable crop farmers in North Central Nigeria. J Hum Ecol 2010;30:1-9.

12. Nyong A, Fiki C. Drought-Related Conflicts, Management and Resolution in the West African Sahel. In: Human Security and Climate Change International Workshop Oslo GECHS, CICERO; 2005. p. 5-16.

13. Okoli AC, Atelhe GA. Nomads against natives: A political ecology of herder/farmer conflicts in Nasarawa state, Nigeria. Am Int J Contemp Res 2014;4:76-88.

14. Ajuwon SS. Case Study Conflict in Fadama Communities in Managing Conflict in Community Development Session 5. Community Driven Development. Abuja: National Fadama Office; 2004. p. 10-5.

15. Okoye BC, Onyenweaku CE, Ukoha OO. An ordered probit analysis of transaction cost and marketing participation small holder cassava farmer in South Eastern Nigeria. Niger Agric J 2010;41:5-10.

16. National Population Commission. Official Gazette, 2006 National Census Figure. Abuja: National Population Commission; 2006.

17. FAO/WFP. Crop and Food Security Assessment Mission to South Sudan. Special Report; 2014. 